AIR WAR COLLEGE

AIR UNIVERSITY

\title{
PETROLEUM DEPENDENCY: THE CASE TO REPLACE THE INTERNAL COMBUSTION ENGINE
}

\author{
by \\ Sidney W. Melton, Colonel, US Army \\ A Research Report Submitted to the Faculty \\ In Partial Fulfillment of the Graduation Requirements \\ Advisor: Dr. Roy F. Houchin II
}

17 February 2015 


\section{Report Documentation Page}

Form Approved

OMB No. 0704-0188

Public reporting burden for the collection of information is estimated to average 1 hour per response, including the time for reviewing instructions, searching existing data sources, gathering and maintaining the data needed, and completing and reviewing the collection of information Send comments regarding this burden estimate or any other aspect of this collection of information,

including suggestions for reducing this burden, to Washington Headquarters Services, Directorate for Information Operations and Reports, 1215 Jefferson Davis Highway, Suite 1204, Arlington

VA 22202-4302 Respondents should be aware that notwithstanding any other provision of law, no person shall be subject to a penalty for failing to comply with a collection of information if it

does not display a currently valid OMB control number

\begin{tabular}{|c|c|c|}
\hline $\begin{array}{l}\text { 1. REPORT DATE } \\
\mathbf{1 7} \text { FEB } 2015\end{array}$ & 2. REPORT TYPE & $\begin{array}{l}\text { 3. DATES COVERED } \\
\mathbf{0 0 - 0 0 - 2 0 1 5} \text { to 00-00-2015 }\end{array}$ \\
\hline \multirow{3}{*}{\multicolumn{2}{|c|}{$\begin{array}{l}\text { Petroleum Dependency: The Case To Replace The Internal Combusion } \\
\text { Engine }\end{array}$}} & 5a. CONTRACT NUMBER \\
\hline & & 5b. GRANT NUMBER \\
\hline & & 5c. PROGRAM ELEMENT NUMBER \\
\hline \multirow{3}{*}{\multicolumn{2}{|c|}{ 6. AUTHOR(S) }} & 5d. PROJECT NUMBER \\
\hline & & 5e. TASK NUMBER \\
\hline & & 5f. WORK UNIT NUMBER \\
\hline \multicolumn{2}{|c|}{$\begin{array}{l}\text { 7. PERFORMING ORGANIZATION NAME(S) AND ADDRESS(ES) } \\
\text { Air War College,,Air University,Maxwell AFB,,AL }\end{array}$} & $\begin{array}{l}\text { 8. PERFORMING ORGANIZATION } \\
\text { REPORT NUMBER }\end{array}$ \\
\hline \multirow{2}{*}{\multicolumn{2}{|c|}{ 9. SPONSORING/MONITORING AGENCY NAME(S) AND ADDRESS(ES) }} & 10. SPONSOR/MONITOR'S ACRONYM(S) \\
\hline & & $\begin{array}{l}\text { 11. SPONSOR/MONITOR'S REPORT } \\
\text { NUMBER(S) }\end{array}$ \\
\hline
\end{tabular}

12. DISTRIBUTION/AVAILABILITY STATEMENT

Approved for public release; distribution unlimited

13. SUPPLEMENTARY NOTES

14. ABSTRACT

In 1876, Dr. Nikolaus Otto invented the internal combustion engine, a revolutionary development providing a lasting impact on all aspects of socio-economic considerations. Yet, it is an inefficient mechanical invention not advancing in 150 years. The reciprocal action of the engine requires two forms of fossil fuel: oil for lubrication and gas for force. This requirement is problematic since the U.S. transportation sector accounts for the predominance of the nearly 19 million barrels of oil consumed per day. Clearly, the inextricable link between the internal combustion engine and oil leads to an inevitable energy security problem. This concern has led President Obama to call for a promotion of alternative energy fuels.

\section{SUBJECT TERMS}

16. SECURITY CLASSIFICATION OF:

a REPORT unclassified b ABSTRACT unclassified c THIS PAGE unclassified
17. LIMITATION OF ABSTRACT

Same as Report (SAR)
18. NUMBER 19a. NAME OF

OF PAGES RESPONSIBLE PERSON

30 


\section{DISCLAIMER}

The views expressed in this academic research paper are those of the author and do not reflect the official policy or position of the US government, the Department of Defense, or Air University. In accordance with Air Force Instruction 51-303, it is not copyrighted, but is the property of the United States government. 


\section{Contents}

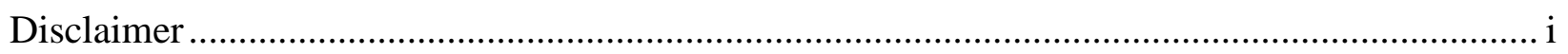

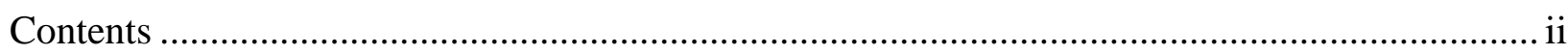

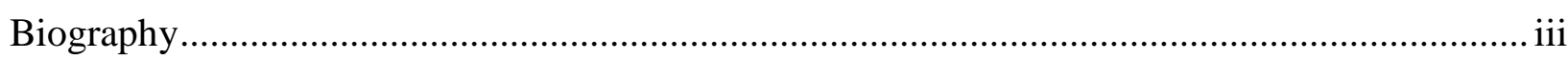

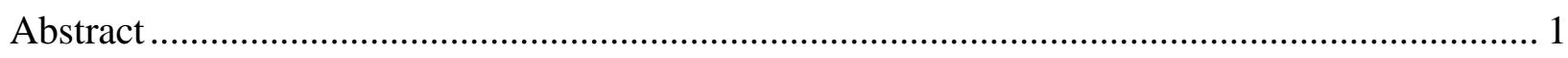

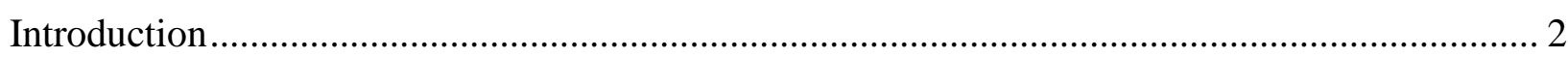

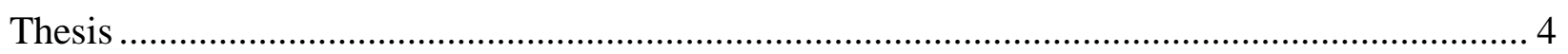

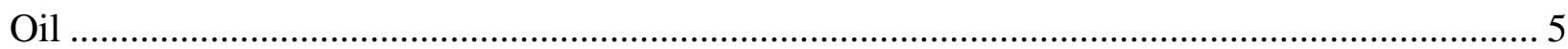

ICE

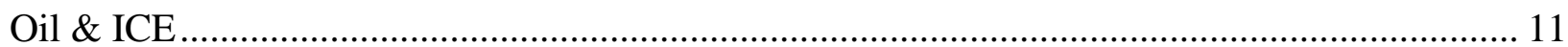

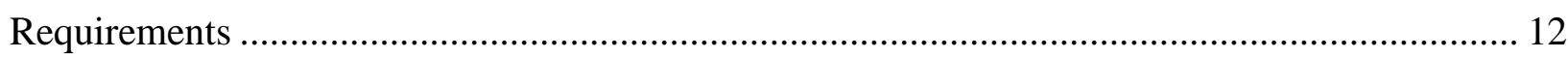

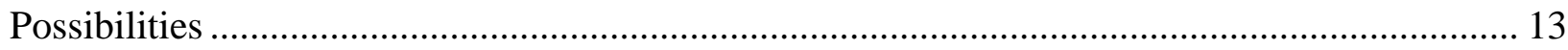

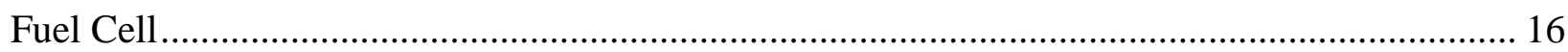

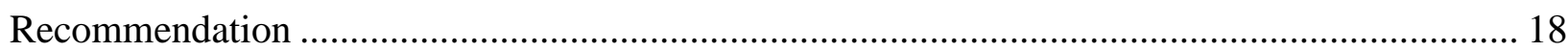

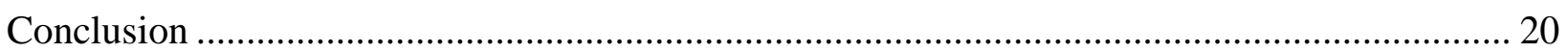

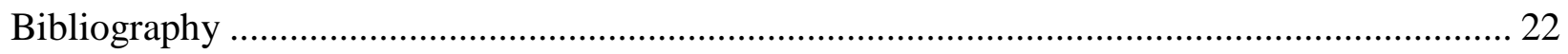




\section{Biography}

Colonel Sidney W. Melton is assigned to the Air War College, Air University, Maxwell AFB, AL. Born in Princeton, Kentucky, he joined the United States Army in January of 1993 and attended One Station Unit Training (OSUT) at Ft. Sill, Oklahoma to become a Field Artillery Cannoneer. Later, he attended Officer Candidate School at Ft. Benning, Georgia where he was commissioned an Ordnance Officer.

During his career, COL Melton served as a Maintenance Platoon Leader/Shop Officer and subsequent Executive Officer, $46^{\text {th }}$ Support Company, Ft. Richardson, Alaska. He held the position of Brigade Maintenance Officer, 3d Signal Brigade, followed by the Supply and Services Officer, $64^{\text {th }}$ Corps Support Group and eventually Company Commander, $602^{\text {nd }}$ Maintenance Company, Ft. Hood, Texas. Next, he was the Future Readiness Officer and Company Grade Assignment Officer, Personnel Command. COL Melton then became the Executive Officer, 82d Sustainment Brigade and Support Operations Officer, Ft. Bragg, North Carolina with deployments in support of Operation IRAQI FREEDOM. His next assignment was as a Joint Operations Officer, United States Military Observers Group, Washington, DC. COL Melton then assumed the position of Battalion Commander, Group Support Battalion, $5^{\text {th }}$ Special Forces Group, Ft. Campbell, Kentucky with deployments in support of Operation IRAQI FREEDOM and Operation NEW DAWN. Before attending the Air War College, COL Melton served as the Logistics Branch Chief, Human Resources Command, Ft. Knox, Kentucky. 


\begin{abstract}
In 1876, Dr. Nikolaus Otto invented the internal combustion engine, a revolutionary development providing a lasting impact on all aspects of socio-economic considerations. Yet, it is an inefficient mechanical invention not advancing in 150 years. The reciprocal action of the engine requires two forms of fossil fuel: oil for lubrication and gas for force. This requirement is problematic since the U.S. transportation sector accounts for the predominance of the nearly 19 million barrels of oil consumed per day. Clearly, the inextricable link between the internal combustion engine and oil leads to an inevitable energy security problem. This concern has led President Obama to call for a promotion of alternative energy fuels.

This paper advocates supporting the President’s strategy by advancing hydrogen fuel cell technology by the U.S. Department of Defense to replace the internal combustion engine. Building the case, this paper highlights the American oil dependency and the perpetual problem the internal combustion engine creates, compares viable alternative engines and recommends a suitable replacement. Finally, the paper proves the Department of Defense must development capabilities to implement fuel cell technology past any status quo scenario.

The fuel cell is an established solution as the National Aeronautics and Space Administration gravitated to this power source starting in the late 1950’s. However, implementation will require Department of Defense to take the initiative, since it is counterintuitive to expect the auto industry or petroleum corporations to interrupt their multibillion dollar a year business. A proper phase-in implementation of hydrogen technology can save lives and money as well as provide a template for a national application and economic security to shift away from its dependence on the internal combustion engine.
\end{abstract}




\section{Introduction}

Noted early 20th century artist Khalil Gibran profoundly quipped, “Progress lies not in enhancing what is, but in advancing toward what will be.” ${ }^{1}$ This passage encompasses a moral obligation for change. However, the internal combustion engine (ICE) is an archaic, paradoxical example of change. While almost every other good has progressed in technology, been replaced, or improved to the point it cannot be compared to the original - the ICE remains mechanically inflexible. More important than the engine's innovative-idleness is the fact it directly tethers Americans to a dependency on fossil fuels.

In the 2015 National Security Strategy, President Obama requires, “... an expanded view of energy security [where]...we must promote diversification of energy fuels and sources.”2 Earlier in his administration the President better specified this directive by saying we must break our dependence on oil, and diversify energy sources and suppliers. ${ }^{3}$ To understand the President's intent one must define the premise concerning this topic. Although there are varying views of where oil comes from, oils are fossil fuels; hydrocarbon deposits, such as petroleum, coal, or natural gas are derived from living matter of a previous geologic time and used for fuel. ${ }^{4}$ Oil is mostly known as crude oil, but includes all liquid hydrocarbon fossil fuels. Petroleum is the most common hydrocarbon fuel and, like all other fuels, requires drilling to extract. The sources of these deposits commonly took millions of years to develop and exist at varying depths within the Earth; petroleum is commonly found 3-5 miles below the surface. Essentially, the fuels the President talks about are not considered renewable since they require millions of years to replace.

\footnotetext{
${ }^{1}$ Karen Fiala, Alterquest: the Alternative Quest for Answers, (Lulu.com, 2006), 127.

${ }^{2}$ The White House, "National Security Strategy" February 2015, 22.

${ }^{3}$ The White House, "National Security Strategy” May 2010, 30.

${ }^{4}$ The Free Dictionary, s.v. "fossil fuel," http://www.thefreedictionary.com/Fossil+fuels, (accessed 26
} September 2014). 
In addition to the term energy, the President uses the term dependence and, even though the word is basic enough to define without the use of a dictionary, it is beneficial to read how starkly Merriam-Webster explains dependence. The reference states, "the quality or state of being dependent; especially: the quality or state of being influenced or determined by or subject to another." ${ }^{5}$ The oil dependency problem is so prolific the lexicon only gives two examples for the word dependency; both refer to dependency on foreign oil. ${ }^{6}$

Our reliance has soared to the point our security is undeniably tied to petroleum resources. Recent events in history illustrate the extraordinary lengths nations take to obtain and safeguard these resources. During Operation BARBAROSSA, Germany opted to invade southwest Soviet Union for oil rather than pushing toward Moscow. Simultaneously, Japan attacked the United States to escape the imposed sanctions and prevent any major opposition to dominating the resources located in the south Pacific, most notably oil. In 1990, Saddam Hussein accused its neighbor of stealing Iraqi petroleum and subsequently invaded the State of Kuwait. The coalition's intervention in 1991 was to liberate the second largest petroleum producer while protecting the allies in the region. In fact, in partial justification of Operation IRAQI FREEDOM, Vice President Dick Cheney said, “Saddam Hussein could...be expected to seek domination of the entire Middle East, [and] take control of a great portion of the world's energy supplies." 7

Not surprisingly, these examples illustrate how leaders use available resources in their calculus. The US's strategic concern for oil is no different. According to the U.S. Energy

\footnotetext{
${ }^{5}$ Merriam-Webster, s.v. “dependence,” http://www.merriam-webster.com/dictionary/dependence, (accessed 26 September 2014).

${ }^{6}$ Merriam-Webster, s.v. “dependency,” http://www.merriam-webster.com/dictionary/dependency (accessed 26 September 2014). The examples given are "the country's dependency on foreign oil," and "a dependency on foreign oil."

${ }^{7}$ The New York Times, "EYES ON IRAQ; In Cheney's Words: The Administration Case for Removing Saddam Hussein,” 27 August 2002, http://www nytimes.com/2002/08/27/world/eyes-iraq-cheney-s-wordsadministration-case-for-removing-saddam-hussein.html.
} 
Information Administration's 2013 petroleum usage report, the United States is the world's largest consumer of oil; nearly twice the volume of oil than the number one energy consumer, China. ${ }^{8}$ This is not to imply a conspiracy theory regarding the use of the military to control the world's oil, but to shed light on why it protects its energy interests as the largest oil consumer sustaining the US's significant transportation requirement. Jeremy Black aptly defines this line of reasoning when he says, "The argument that wars are fought to gain control of oil is overly simplistic, but the availability of oil is certainly very important...and notably for the use of the internal combustion engine.”9

As a result, energy independence in the transportation sector is a key to the US's long term security. In fact, the relationship between energy security and national security is important enough for President Obama to establish the Office of the Assistant Secretary of Defense for Operational Energy Plans and Programs (OASD (OEPP)). ${ }^{10}$ Without question, the ICE powers nearly all vehicles and, by the transitive theory, a technological revolution of the power source would eliminate the US’s dependency on oil and provide security to the Nation.

To accomplish supporting the President's strategy to further develop energy security requires an advancement of the hydrogen fuel cell technology by the U.S. Department of Defense (DoD) to replace the internal combustion engine. By examining the oil dependency on the American economy, its linkage to the complacency of the ICE reveals a demand for a viable alternative engine; the civilian industrial base cannot be relied upon to support anything other

${ }^{8}$ U.S. Energy Information Administration, “China,” http://www.eia.gov/countries/countrydata.cfm?fips=ch (accessed 9 October 2014). EIA says China is the World's second-largest oil consumer behind the United States regardless of the fact they are the largest global energy consumer.

${ }^{9}$ Jeremy Black, War and Technology, (Indiana University Press, Bloomington, IN, 2013), 172.

${ }^{10}$ Department of Defense, Fiscal Year 2012, Operational Energy Annual Report, http://energy.defense.gov/Portals/25/Documents/Reports/20131015_FY12_OE_Annual_Report.pdf, 2. (accessed 11 November 2014). 
than a status quo scenario, and recommends DoD research and development capabilities to implement fuel cell technology.

\section{Oil}

The early years of oil exploration are closely associated with independent expanding petroleum companies based out of colonial powers, and provided no stabilizing effect on production, distribution or pricing. Certainly, one of the most solidifying decisions to provide predictability for the oil industry was the formation of the Organization of the Petroleum Exporting Countries (OPEC) in 1960. Today the organization has 12 members; their mission "is to coordinate...the stabilization of oil markets in order to secure an efficient, economic and regular supply of petroleum to consumers, a steady income to producers and a fair return on capital for those investing in the petroleum industry."11 Essentially, OPEC provides control over oil production to regulate the supply and demand model. Collectively, OPEC is the leading producer of crude oil, establishing stable gas prices to the consumer with a resulting increase in sales. ${ }^{12}$ Indeed, a trillion dollars revenue in a year provides a substantial amount of economic security.

The current economic security the oil industry provides has not eluded the United States. Fortune Magazine states oil companies hold four of the top ten domestic revenue producing positions in 2014. ${ }^{13}$ All four companies turned profits, but more significantly: Exxon Mobil, Chevron, Phillip 66, and Valero combined to produce $\$ 926$ billion in revenues - $\$ 100$ billion

\footnotetext{
${ }^{11}$ Organization of the Petroleum Exporting Countries, Our Mission, http://www.opec.org/opec_web/en/about_us/23 htm (accessed 21 October 2014).

${ }^{12}$ U.S. Energy Information Administration, "OPEC Revenues Fact Sheet," http://www.eia.gov/countries/regions-topics.cfm?fips=OPEC (accessed 21 October 2014).

${ }^{13}$ Fortune 500, “Fortune 500 2014,” http://fortune.com/fortune500/ (accessed 6 November 2014).
} 
more than the 12 OPEC nations combined. ${ }^{14}$ Most notably, the United States has recently increased oil production and is prepared to surpass OPEC’s production by $2017 .^{15}$

Markedly, the collective oil industry provides an economic security producers, distributors and consumers enjoy. However, a widely discussed issue involves the limited amount of oil remaining. With the global demand of oil increasing, the dependence on oil and the finite amount remaining makes for a potentially volatile economic sector. Since businesses focus on revenue for their stockholders, a diminishing product will force extraordinary prices with little room for profit. Recent business announcements indicate the possible future of the oil industry. First, the Rockefeller Brothers Fund originally made its fortune through the Standard Oil Company; recently, it announced a “desire to divest from investments in fossil fuels.”16 Secondly, three foreign automobile makers announced at recent auto shows they would release hydrogen fuel cell vehicles within the year. ${ }^{17}$ These indicators suggest there is ample time to begin a phased-transition to a diversified energy source and deliver economic security.

In 2014, an average of 92.7 million barrels of oil were consumed per day in the world. ${ }^{18}$ In comparison, recent domestic figures indicate 18.9 million barrels per day are consumed. ${ }^{19}$ This total reflects the largest amount of oil expended by any other country, and nearly twice as much as China. Not surprisingly the transportation sector accounts for the largest share of total

14 Ibid.

${ }^{15}$ U.S. Energy Information Administration, “OPEC Revenues Fact Sheet,” http://www.eia.gov/countries/regions-topics.cfm?fips=OPEC (accessed 21 October 2014).

16 The New Yorker, “The Rockefeller Brothers Fund Gives Up on Oil,” 23 September 2014, http://www.newyorker.com/business/currency/rockefellers-give-oil.

${ }^{17}$ The Huffington Post, "Hydrogen Cars Showcased At Los Angeles Auto Show Could Be Future Of Transportation,” 21 November 2013, http://www huffingtonpost.com/2013/11/21/hydrogen-cars-la-autoshow_n_4317569.html.

${ }^{18}$ Bloomberg, "IEA Raises 2014 Oil Demand Estimate As World Economy Recovers,” 14 March 2014, http://www.bloomberg.com/news/2014-03-14/iea-raises-2014-oil-demand-estimate-as-world-economyrecovers html.

${ }^{19}$ U.S. Energy Information Administration, "How much oil is consumed in the United States?," http://www.eia.gov/tools/faqs/faq.cfm?id=33\&t=6 (accessed 21 October 2014). 
domestic petroleum consumption. ${ }^{20}$ Within the transportation sector, the vehicular mode of transportation consumes the greatest amount of oil at $59 \% .{ }^{21}$ This is due to the fact there are over 250 million domestic registered vehicles. ${ }^{22}$

Within the United States, DoD is the largest oil consuming government body. ${ }^{23}$ The 2012 U.S. Energy Information Administration reported DoD consumed nearly half of a million barrels of oil per day. ${ }^{24}$ The number makes DoD the single largest consumer of petroleum in the United States and is significant enough for Secretary of Defense Chuck Hagel to commit to "improving the energy performance of aircraft, ships, ground vehicles and military bases; reducing the vulnerability of our fuel supply lines; decreasing the load our expeditionary forces must carry; and diversifying the energy supplies we use.”25

\section{ICE}

As previously mentioned, petroleum is inextricably linked to the ICE, but to understand this importance it helps to recognize why they are connected. An ICE is a reciprocal engine creating force derived from converting chemical energy into mechanical energy. This process starts with an explosion created by a reaction of fossil fuel, air, electronic spark, and ends with the power stroke of the piston within a cylinder combustion chamber. During the course from the explosion to the power stroke, the ICE simultaneously consumes two forms of fossil fuel.

\footnotetext{
${ }^{20}$ U.S. Energy Information Administration, “Annual Energy Outlook 2014,” http://www.eia.gov/forecasts/aeo/mt_liquidfuels.cfm (accessed 28 October 2014).

${ }^{21}$ Center for Climate and Energy Solutions, “Transportation Energy Use by Mode (2012).” http://www.c2es.org/energy/use/transportation (accessed 21 October 2014).

${ }^{22}$ United States Department of Transportation, Bureau of Transportation Statistics, http://www.rita.dot.gov/bts/sites/rita.dot.gov.bts/files/publications/national_transportation_statistics/html /table_01_11.html (accessed 6 November 2014).

${ }^{\overline{23}}$ Sharon E. Burke, "Powering the Pentagon: Creating a Lean, Clean Fighting Machine,” Foreign Affairs, June 2014, http://www.foreignaffairs.com/articles/141207/sharon-e-burke/powering-the-pentagon.

${ }^{24}$ U.S. Energy Information Administration, “Annual Energy Outlook 2014,” http://www.eia.gov/forecasts/aeo/ (accessed 28 October 2014).

${ }^{25}$ Department of Defense, Fiscal Year 2012, Operational Energy Annual Report, http://energy.defense.gov/Portals/25/Documents/Reports/20131015_FY12_OE_Annual_Report.pdf, 8. (accessed 11 November 2014).
} 
First, the engine has a mechanical necessity for oil as a lubricant. Requiring approximately six quarts at a time, the oil resides in the oil pan until called upon to serve its only function - reduce friction on the pistons. This action prevents unnecessary wear and tear on the engine. The second is the engine's constant requirement for gas, the vehicle's energy source. At present, the efficiency of gas combined with the common size of fuel tanks permit vehicles to travel an average of 300 miles before requiring refueling.

This lineage of the ICE is well documented, but the invention is attributed to a myriad of inventors. ${ }^{26}$ However this paper recognizes in 1876, Dr. Nikolaus August Otto invented a fourstroke engine, known as the "Otto cycle."27 This invention was significant for two reasons. First, the Otto-mobiles we drive today are directly named after him, and what most people recognize as the first ICE. Secondly, and most importantly, is the fact the four-stroke engine Otto invented is nearly identical to the internal mechanism of today's engines.

Today, the automobile industry is a multi-billion dollar a year business. From the invention of the engine/automobile through the advent of mass production, the car has become more than just a means of transportation to the world. Yet, decades ago following World War II, the sole consideration of transportation when purchasing a vehicle was replaced by the name brand, and/or how much you paid for the vehicle. This illustrates how the vehicle became more of a status symbol to the consumer than a means of transportation. More surprisingly, successful advertising campaigns allowed automobile corporations to influence families to buy more frequently in order to stay ahead of the proverbial Jones's.

${ }^{26}$ About.com, The History of the Automobile, The Internal Combustion Engine and Early Gas-Powered Cars, http://inventors.about.com/library/weekly/aacarsgasa.htm (accessed 23 September 2014). Although not all inclusive, there are various sources that attribute the internal combustion engine's development to a multitude of inventors such as the American inventor, Samuel Morey by C. Lyle Cummins Jr.'s, Internal Fire and Jay Leno's, "An Unknown American Classic," Popular Mechanics, Jul. 2003.

${ }^{27}$ P.M. Heldt, High Speed Combustion Engines: Design: Production: Tests, (Chilton Company, Philadelphia, PA, 1956), 1. 
Even though the automobile is fashionable, it was slow to catch on. In fact, the ICE was slower to gain acknowledgement than other types of engines. However, once the public began to accept the automobile as a replacement to the horse it began to spread like an uncontrollable forest fire. Most will agree it changed and improved everyday life from a point where every family owned multiple horses to now, where everyone owns multiple cars - and no horses. This type of economic swing made it very enterprising for a myriad of industries: automotive, tire, maintenance/service, and most importantly petroleum production.

Following the industrial revolution, the late 19th century produced arguably the largest collection of influential inventions. With the likes of Kodak, Bell, Edison, and Tesla the public enjoyed the creations of camera film, telephone, record player, and conversion of electricity into mechanical energy. It was during this same timeframe Nikolaus Otto patented his four-stroke engine. In fact, the U.S. Patent and Trademark Office granted a record of over 25,000 patents in 1890; a great time for advancements. ${ }^{28}$

Currently, those same inventors are revered for their technological revolutions transforming life and shaping subsequent civilizations. However, most of their inventions are no longer comparable to the original. George Kodak's inexpensive camera film made it possible for most Americans to own a camera, advancing to today's digital camera no longer requiring film. Alexander Graham Bell's telephone has long since discarded its receiver-cord in exchange for today's palm-sized smartphone with the ability to call from nearly anywhere in the world. Thomas Edison's record player also shed its stationary limitation for today's portable digital music players. Innovation is moving at an exponential pace when considering the rate of change.

\footnotetext{
${ }^{28}$ United States Patent and Trademark Office, U.S. Patent Activity Calendar Years 1790 to the Present, http://www.uspto.gov/web/offices/ac/ido/oeip/taf/h_counts.htm (accessed 6 November 2014).
} 
In 2013, the U.S. Patent and Trademark Office granted more than ten times the amount of patents than in $1890-277,835 .^{29}$

With all of those advancements it is scary to think some technologies are lagging. Not much has changed since the invention of the ICE almost 200 years ago. The addition / subtraction of cylinders, the configuration of the cylinders, and maybe even how the engine gets the fuel, but essentially it is still a four-stroke engine; not to mention it is price sensitive and resource intensive. Today you may get a little overwhelmed when you look under your car hood, but down deep it is still the same four-stroke engine Nikolaus Otto devised in 1876.

There are many devotees who argue the ICE only needs continual evolutions in performance and efficiency. Their argument is grounded in the fact the ICE can only be improved, but never replaced. They illustrate their argument by stating, “...make a better mousetrap, [and] the world will make a beaten path to his door.”30

The ICE is not efficient. Following 200 years of evolution, the laws of thermodynamics limits the conventional engine to $14 \%-30 \%$ of efficiency depending on the cycle. ${ }^{31}$ Commonly, the popular 4-stroke engine’s efficiency looms around the lower percentage, resulting in a mechanical process where $86 \%$ of the heat generated is displaced. This low efficiency creates lower miles-per-gallon ratings, because the engine uses more fuel to generate heat than it does to provide motion. Although a 14\% efficiency rating is tolerable in an ICE, no one would tolerate an employee with similar efficiency ratings. In fact if the tables were turned, it would not take

${ }^{29}$ Ibid.

${ }^{30}$ Ralph Waldo Emerson, “The Mousetrap Quotation,” The Docket, West Publishing Company, (Feb 1912), 1, 651-652, http://books.google.com/books?id=dMRBAAAAYAAJ\&pg=PA651\#v=onepage\&q\&f=false (accessed 16 February 2014).

${ }^{31}$ U.S. Department of Energy, Where the Energy Goes: Gasoline Vehicles, http://www.fueleconomy.gov/feg/atv.shtml (accessed 9 October 2014). 
anyone long to find new employment if you merely got paid for 14\% of effort; essentially, 14\% of a $\$ 400.00$ pay period would earn you an unacceptable $\$ 56.00$ paycheck.

\section{Oil \& ICE}

Those figures are eye-opening, but there are those supporters who stand by the fact petroleum fuel is relatively cheap. This is an old argument predating the 1973 Oil Embargo, when gas prices were inexpensive compared to earned income. Since then, the $\$ 0.36$ average cost for a gallon of gas has skyrocketed $880 \%{ }^{32}$ During the same time period the median income only rose $345 \% .{ }^{33}$ Currently, oil prices dipped to a five-year low. However, those types of situations are temporary since the price per barrel of oil is determined by its dynamic commodity trading on the New York Mercantile Exchange (NYMEX) and is tied to the global economic growth outlook. ${ }^{34}$ This price modeling is problematic, because peak lows or highs for fuel prices are attached to impending recessions or inflation created from expansion. Yet, the volatility of gas prices are moot when considering we are reliant on a finite natural resource whose eventual unobtainable prices will foreshadow the public cries for the depleting resource. The precarious state of gas prices impact the customer and serve as additional proof it is time to break our oil addiction and move to an energy source based on the supply and demand business model and not the global economic growth index.

Secondly, the continued use of petroleum products in an ICE is environmentally irresponsible. The effects of vehicle emissions are accountable for a number of adverse

\footnotetext{
${ }^{32}$ U.S. Department of Energy, Average Retail Price of Gasoline, 1929-2013, http://energy.gov/eere/vehicles/fact-835-august-25-average-annual-gasoline-pump-price-1929-2013 (accessed 9 October 2014).

${ }^{33}$ United States Census Bureau, Table P-1. CPS Population and Per Capita Money Income, All Races: 1967 to 2013, https://www.census.gov/hhes/www/income/data/historical/people/2013p01AR.xls (accessed 9 October 2014).

${ }^{34}$ Katina Stefanova, “Do Falling Oil Prices Foreshadow a Slump in the Stock Market in 2015?,” Forbes, 31 December 2014, http://www.forbes.com/sites/katinastefanova/2014/12/31/do-falling-oil-prices-foreshadow-a-slumpin-the-stock-market-in-2015/.
} 
environmental pollutants, air quality, ozone damage, and reduced visibility. Depending on the environmental theory, this may also include global warming and its subsequent effects.

However arguable, there are two remaining facts: fossil fuel use harms the environment and carbon-monoxide is considered harmful to public health. ${ }^{35}$ Separately, those issues are cause for concern, but collectively they can affect our existence.

When conceding to the above argument, supporters of the ICE would subsequently advocate for the use of biofuels. The U.S. Government defines biofuels as "liquid fuels and blending components produced from biomass feedstocks, used primarily for transportation.”36 Examples of these organic fuels include ethanol, biodiesel, and vegetable oil. The use of these products appears to eliminate the dependency on petroleum and could eventually become cost effective, but producing biofuels creates a competition for the same resources feeding humans: land and water. In addition, the simple fact remains, biofuels keep us tied to the ICE; in turn, this technology still requires oil for lubrication, worsens certain types of air pollution, and is an illogical mechanism for transportation indefinitely. ${ }^{37}$

\section{Requirements}

Over four decades of U.S. Presidents demanded petroleum independence without progress. The political rhetoric during this timeframe is consequential to the increase of the domestic demand. In 1974, when Americans consumed 16.7 million barrels of oil a day, and $36.1 \%$ of it originated from foreign sources, President Richard Nixon said, "At the end of this decade, in the year 1980, the US will not be dependent on any other country for the energy we

\footnotetext{
${ }^{35}$ United States Environmental Protection Agency, National Ambient Air Quality Standards (NAAQS), Carbon Monoxide (CO) Standards, http://www.epa.gov/ttn/naaqs/standards/co/s_co_index.html (accessed 4 February 2015).

${ }^{36}$ U.S. Energy Information Administration, s.v. "biofuel," http://www.eia.gov/tools/glossary/index.cfm?id=B (accessed 29 October 2014).

${ }^{37}$ Alister Doyle, "Biofuels cause pollution, not as green as thought - study," Reuters, 7 January 2013, http://www.reuters.com/article/2013/01/07/us-climate-biofuels-idUSBRE90601A20130107.
} 
need.” ${ }^{38}$ Through the years oil consumption increased to the extent President George W. Bush declared, "America is addicted to oil." ${ }^{39}$ By 2009, domestic oil consumption elevated to just below 20 million barrels of oil a day with $66.2 \%$ of it from foreign sources; President Obama addressed this issue by stating, "It will be the policy of my administration to reverse our dependence on foreign oil while building a new energy economy."40 Since then, President Obama has decreased the US's purchase of foreign oil, only to have it replaced by an increase in domestic oil production and a 18.9 million barrels per day consumption. ${ }^{41}$

Regardless of political party, eight straight presidents prove there is a global energy security obtained by distancing ourselves from oil dependency. Earlier, oil was shown to be a limited resource with a sine wave-like price modeling system. More importantly, the ICE is an archaic, inefficient and environmentally irresponsible invention tying consumers to oil. Independently these issues demand our attention, yet as a collection they reflect an obligation for change.

\section{Possibilities}

The United States could greatly benefit from transitioning to a fuel cell based industry. This suggestion does not advocate for the Nation to relinquish its lead position in the oil/automotive market. On the contrary, it recommends those goods and services markets should transition to hydrogen production and distribution in addition to its current oil-based industries.

\footnotetext{
38 The American Presidency Project, Richard Nixon State of the Union Address, 30 January 1974, http://www.presidency.ucsb.edu/ws/?pid=4327 (accessed 9 October 2014).

39 Elisabeth Bumiller and Adam Nagourney, "Bush: 'America is addicted to oil'," The New York Times, 1 February 2006, http://www.nytimes.com/2006/02/01/world/americas/01iht-state html?pagewanted=all\&_r=0.

40 The White House, Public Papers of the Presidents of the United States: Barack Obama, (2009, Book 1) (U.S. Government Publishing Office, 2009), 29, http://www.gpo.gov/fdsys/pkg/PPP-2009-book1/pdf/PPP-2009book1.pdf.

${ }^{41}$ U.S. Energy Information Administration, “How much oil is consumed in the United States?,” http://www.eia.gov/tools/faqs/faq.cfm?id=33\&t=6 (accessed 21 October 2014).
} 
Through this transition, domestic industries would continue a dominate approach to initialize and influence the fuel cell development and job markets reinforcing its economic power.

The dominance of the ICE's advantages like longer driving ranges, inexpensive production and operation costs, and established infrastructure give the appearance it will be around forever. Yet, with all of those compelling reasons to stay with the ICE, there are greater reasons to explore alternatives. In fact, there is no logical reason to stay with the antiquated, inefficient invention when technologies exist surpassing ICE's capabilities and its reliance on fossil fuels. Researchers have advanced and produced viable alternatives such as solar, electricity, and fuel cell engines.

First, solar is a practical power source collecting sunlight, converting it into energy, storing it in batteries, or translating the energy into motion. It is considered a renewable energy source since the Sun is expected to shine for billions of years. In addition, it is a source producing no emissions. Most important to consumers is the fact refueling does not have any associated costs.

With so many appealing advantages, it is hard to envision why industries have not transitioned to the production of solar powered cars. The answer to this question resides in the fact solar cars have numerous draw-backs. Hard to ignore, the energy source provides modest reliability, since the Sun cannot be expected to shine every day. In addition, solar power does not create large quantities of force. Due to this issue, the vehicle is required to minimize weight through the use of limited occupancy / space, and expensive materials. Above all, consumers are drawn to solar since there is no refueling cost; however, cost-avoidance quickly vanishes due to extremely expensive cost for materials and maintenance. Unlike many start-up costs, solar power's problems cannot be solved by mass production. Most importantly, an engine with no 
associated refueling cost results in unintended economic repercussions with losses of jobs/revenue in the energy industrial base.

Second, electric cars are a useful option for replacing the ICE. With existing productions by Nissan, Chevrolet, Ford, and Tesla there is a public curiosity causing individuals to take notice. Predominately this is due to the fact consumers can avoid gas stations translating to approximately $\$ 2,500$ a year. Like the other alternative engines, it is a cleaner energy source than petroleum. Yet, one of the strongest attraction factors for consumers is the cost-avoidance. Savings are evidenced with the combination of less expensive purchase prices on some models and the addition of a $\$ 7,500$ federal income tax credit. ${ }^{42}$

Clearly there are a lot of advantages to the electric vehicle, but significant disadvantages have consumers waiting for solutions. One of the draw-backs is high manufactures suggested retail price on most models. This may be confusing since I mentioned above some versions were inexpensive. The difference in cost varies depending on how far you want your car to be able to travel. The Chevy Volt does not go far before needing recharged, yet vehicles from Tesla Motors cost upwards of $\$ 100,000$ and can carry you further than an ICE. Conversely, the price for traveling distance on a single charge is troubling when compared against the ICE whose higher miles per gallon ratings are seen in the less expensive vehicles. In addition, there is a lack of recharging stations for the consumer's convenience, and will always be one of the biggest issues for electric cars. However, the most significant issue for consumers to overcome is while

\footnotetext{
${ }^{42}$ U.S. Department of Energy, Federal Tax Credits for Electric Vehicles Purchased in or after 2010, http://www.fueleconomy.gov/feg/taxevb.shtml (accessed 28 October 2014).
} 
refueling a gas-fueled car takes less than 5 minutes, recharging a Tesla Model S takes 59

minutes. $^{43}$

\section{Fuel Cell}

In 1839, Welsh judge and physical scientist, Sir William Robert Grove published in The London and Edinburgh Philosophical Magazine and Journal of Science his concept for the first crude fuel cell. ${ }^{44}$ However by 1958, two General Electric chemists, W. Thomas Grubb, and Leonard Niedrach, devised a way of depositing platinum onto a membrane serving as a catalyst for the necessary chemical reaction to produce energy from a fuel cell. ${ }^{45}$ This invention became known as the Grubb-Niedrach fuel cell and went on to be used by the National Aeronautics and Space Administration (NASA) for subsequent missions. ${ }^{46}$ Today, on each space mission fuel cells independently power propulsion for transportation, power generation for electricity, and life support systems like breathable air production.

Powered by hydrogen, the fuel cell is environmentally conscience and hydrogen is the simplest and most readily available element in the world, constituting roughly $90 \%$ of the atoms in existence. ${ }^{47}$ In addition, the fuel cell engine is $60 \%$ efficient with its energy conversion. ${ }^{48}$

${ }^{43}$ Edmunds, 2013 Telsa Model S Long-Term Road Test, 7 October 2013, http://www.edmunds.com/tesla/model-s/2013/long-term-road-test/2013-tesla-model-s-how-quickly-does-asupercharger-charge.html (accessed 21 October 2014).

${ }^{44}$ William R. Grove, "Mr. W. R. Grove on a new Voltaic Combination,” The London and Edinburgh Philosophical Magazine and Journal of Science, Vol. XIII (July - December 1838): 430, https://books.google.com/books?id=9XkqAAAAYAAJ\&pg=PA430\&lpg=PA430\&dq=\%22Mr.+W.+R.+Grove+on $+\mathrm{a}+$ new+Voltaic+Combination\%22\&source=bl\&ots=Mm5zFImc3m\&sig=96TE9FizbPJXuVZUxEcwCNT6wgo\&h $\mathrm{l}=$ en\&sa=X\&ei=3dbcVIXkHPbdsASn34KYBw\&ved=0CCAQ6AEwAQ\#v=onepage\&q=\%22Mr.\%20W.\%20R.\%2 0Grove\%20on\%20a\%20new\%20Voltaic\%20Combination\%22\&f=false (accessed 11 November 2014).

${ }^{45}$ Smithsonian Institute, Fuel Cell History, http://americanhistory.si.edu/fuelcells/pem/pem2 htm (accessed 11 November 2014). November 2014)

${ }^{46}$ Fuel Cell Today, “The Space Programme,” http://www.fuelcelltoday.com/history (accessed 11

${ }^{47}$ How Stuff Works, How Hydrogen Cars Work, http://auto.howstuffworks.com/fuel-efficiency/hybridtechnology/hydrogen-cars2.htm (accessed 24 September 2014).

${ }^{48}$ How Stuff Works, What's the energy efficiency ratio for hydrogen fuel cells?, http://auto.howstuffworks.com/fuel-efficiency/fuel-saving-devices/energy-efficiency-ratio-hydrogen-fuel-cell1 htm (accessed 24 September 2014). 
With the use of hydrogen, it produces a powerful and better source of energy. The prospects of such an environmentally conscience innovation has many Americans demanding its development and sourcing. These potential consumers see many up-sides to hydrogen fuel as readily available, no harmful emissions, an environmental improvment, renewable, and it is highly efficient.

Those consumers should realize the fuel cell's potential down-sides. Hydrogen is not transferable in the same distribution systems petroleum currently uses, it does not have a support infrastructure, it is flammable, and it is expensive to separate from other compounds. This last point is important since hydrogen is not monoatomic and only exists combined with other elements, since it is too light to exist singularly. As a result, the process for separating the hydrogen molecule to a lone form takes energy. Currently there are two methods of producing hydrogen, yet both are more costly than producing fuels like gasoline: electrolysis and steam reformation.

The first method uses steam reforming to create a synthesis gas. A steam reformer is an invention using steam heat to strip the hydrogen atom from a hydrocarbon; electricity is generated from the hydrogen. This process is the most commonly used, but actually uses natural gas during the process; counter-logical to the fossil fuel dependency argument.

The second method, electrolysis, uses electrical energy to separate the hydrogen and oxygen atoms in water molecules. This preferable method is accomplished through the use of renewable fuels or solar energy. In fact, researchers are working on techniques to provide enough electric current to mass-produce hydrogen. The electrolysis process is currently cost prohibitive, yet by creating a mass-production method the process can become cost effective and possibly the most common. 


\section{Recommendation}

The United States should support the President’s strategy to advance energy security with alternative energies. Early in President Obama's first term, he said we needed access to transforming the way we produce and use energy, so we reduce our dependence on fossil fuels. The administration stands by the fact access to energy may be "one of the most powerful ways to support social and economic development." ${ }^{49}$ His intent is easily achieved by replacing the ICE with the fuel cell. Adopting this technology will accomplish many objectives laid out by the President. First, with an investment in the infrastructure, hydrogen fuel cells can immediately begin being offered by automobile makers. Second, in a relatively short amount of time, fuel cell technology can eliminate the US's dependency on petroleum - essentially removing the energy security issue plaguing the Nation for decades. Lastly, American industry can capitalize on this immerging energy source, retain their high revenues, provide jobs, and boost the economy.

Likewise, the benefits for fuel cell technology in DoD is tremendous. It can provide a energy source capable of being produced in garrison, and on operating bases eum to meet forecasted fuel requirements. Essentially, since hydrogen production can takes place locally, fuel is fashioned only when needed. It can provide an energy source capable of being produced in garrison, and on operating bases while deployed. This circumvents the need to purchase, transport, and distribute petrol in saved lives, and preserves equipment by removing the necessity to put service members and distribution vehicles on the road in harm's way.

DoD previously acknowledged the value of fuel cell technology. In 2012, the department established a memorandum of agreement with interagency partners to develop uses for new

\footnotetext{
${ }^{49}$ The White House, “National Security Strategy” May 2010, 28.
} 
technologies. One of the prioritized initiatives is a joint program with the Department of Advanced Research Projects Agency-Energy (DARPA-E) to use Hybrid Energy Storage Modules (HESM). Its aims “are to develop modular hybrid energy storage technology that addresses long endurance and rapid charge/discharge needs for forward operating bases, aircraft power management, and future shipboard weapons systems." ${ }^{50}$

The only aspect missing is the inclusion of vehicles. Currently, DoD is looking at electric powered vehicles. However, it was proven earlier how inconvenient and untimely recharging electric powered vehicles are. The department would greatly benefit from a power source rechargeable in moments, versus one in greater than 30 minutes. Likewise, it could capitalize on similar energy sources across multiple Services and platforms.

This possibility will require DoD to develop and implement, since it is counterintuitive to expect the auto industry, petroleum corporations, or oil producing countries to take the initiative. Those industries could be expected to slow-roll the developing technology since it poses a threat to their current economic security.

The initial fuel cell implementation will require a phase-in approach beginning with DoD's plan to implement fuel cell power in basing, followed by aircraft and naval fleets. Different from DoD's current plan is the inclusion of tactical vehicles. However, the vehicular implementation plan should only include newly acquired automobiles. This plan does not advocate for the engine replacement of the older petroleum-fueled fleet. It is beneficial to exempt those vehicles and allow them to phase-out at the end of their monetary usefulness. This plan will save money, maintain readiness, and complement the infrastructure implementation of hydrogen fueling systems while antiquated vehicle platform inventories dwindle away.

${ }^{50}$ Department of Defense, Fiscal Year 2012, Operational Energy Annual Report, 6, http://energy.defense.gov/Portals/25/Documents/Reports/20131015_FY12_OE_Annual_Report.pdf. (accessed 11 November 2014). 
The inclusion of fuel cell technology in commercial vehicles will require an initiation plan similar to DoD’s proposed plan. It would utilize a start-up date for the new vehicles and a phase-out plan for previous models. The U.S. President can announce a strategy incorporating this established technology in all new commercial vehicles subsequently kick-starting the technology to become more cost effective. The main cost comes in the initial investment, but an incentive package would spark the liquidity of the market and offset the beginning venture. Akin to the electric vehicle federal income tax credit mentioned earlier, an incentive directed to the consumer to help persuade them to purchase a new technology. As a suitable option for the oil corporations, the legislative branch could easily rewrite the Enhanced Oil Recovery (EOR) Tax Credit, and the Marginal Well Tax Credit subsidies and redirect it towards hydrogen power production. Likewise, similar subsidies could be established to include the automobile industries to boost fuel cell production. Currently, domestic oil-related subsidies total $\$ 4.5$ billion a year. ${ }^{51}$ However, the term 'subsidies' is a misnomer; the incentivized industries do not receive monetary payments, yet there are sections in the tax code allowing companies to recover their costs.

\section{Conclusion}

Supporting the President's strategy to become energy independent can be accomplished by requiring an advancement of the fuel cell technology by DoD to replace the ICE. The continued use of the ICE maintains the demand for fossil-based petroleum. However, fuel cell energy offers the United States a secure energy source and has the potential to stabilize future fuel and transportation industries. Due to conflicts of interest within the oil and auto industry's economic base, it is inherent upon DoD to leverage its research and development capabilities to implement fuel cell technology. A proper implementation of hydrogen technology by DoD can

\footnotetext{
${ }^{51}$ Robert Rapier, “The Surprising Reason That Oil Subsidies Persist: Even Liberals Love Them,” Forbes, 25 April 2012, http://www forbes.com/sites/energysource/2012/04/25/the-surprising-reason-that-oil-subsidiespersist-even-liberals-love-them/.
} 
save lives and money as well as provide a template for national application and economic security to shift away from its dependence on ICE and its infrastructure. 


\section{BIBLIOGRAPHY}

About.com. The History of the Automobile. The Internal Combustion Engine and Early Gas-Powered

Cars. http://inventors.about.com/library/weekly/aacarsgasa.htm (accessed 23 September 2014).

The American Presidency Project. Richard Nixon State of the Union Address, 30 January 1974. http://www.presidency.ucsb.edu/ws/?pid=4327 (accessed 9 October 2014).

Black, Jeremy. War and Technology. Bloomington, IN. Indiana University Press, 2013.

Bloomberg. “IEA Raises 2014 Oil Demand Estimate As World Economy Recovers,” 14 March 2014. http://www.bloomberg.com/news/2014-03-14/iea-raises-2014-oil-demandestimate-as-world-economy-recovers.html.

Bumiller, Elisabeth and Adam Nagourney. “Bush: 'America is addicted to oil'.” The New York Times, 1 February 2006. http://www.nytimes.com/2006/02/01/world/americas/01ihtstate.html?pagewanted=all\&_r=0.

Burke, Sharon E. "Powering the Pentagon: Creating a Lean, Clean Fighting Machine.” Foreign Affairs, June 2014. http://www.foreignaffairs.com/articles/141207/sharon-eburke/powering-the-pentagon.

Center for Climate and Energy Solutions. “Transportation Energy Use by Mode (2012).” http://www.c2es.org/energy/use/transportation (accessed 21 October 2014).

Department of Defense. Fiscal Year 2012, Operational Energy Annual Report. http://energy.defense.gov/Portals/25/Documents/Reports/20131015_FY12_OE_Annual_ Report.pdf. (accessed 11 November 2014).

Doyle, Alister. "Biofuels cause pollution, not as green as thought - study.” Reuters, 7 January 2013. http://www.reuters.com/article/2013/01/07/us-climate-biofuelsidUSBRE90601A20130107.

Edmunds. 2013 Telsa Model S Long-Term Road Test, 7 October 2013. http://www.edmunds.com/tesla/model-s/2013/long-term-road-test/2013-tesla-model-show-quickly-does-a-supercharger-charge.html (accessed 21 October 2014).

Emerson, Ralph Waldo. “The Mousetrap Quotation.” The Docket, (Feb 1912) http://books.google.com/books?id=dMRBAAAAYAAJ\&pg=PA651\#v=onepage \&q\&f=f alse (accessed 16 February 2014).

Fiala, Karen. Alterquest: the Alternative Quest for Answers. Lulu.com, 2006.

Fortune 500. “Fortune 500 2014.” http://fortune.com/fortune500/ (accessed 6 November 2014). 
The Free Dictionary. http://www.thefreedictionary.com/Fossil+fuels, (accessed 26 September 2014).

Fuel Cell Today. “The Space Programme.” http://www.fuelcelltoday.com/history (accessed 11 November 2014).

Grove, William R. "Mr. W. R. Grove on a new Voltaic Combination.” The London and Edinburgh Philosophical Magazine and Journal of Science, Vol. XIII (July - December 1838).

https://books.google.com/books?id=9XkqAAAAYAAJ\&pg=PA430\&lpg=PA430\&dq=\% 22Mr.+W.+R.+Grove+on+a+new+Voltaic+Combination\%22\&source=bl\&ots=Mm5zFI mc3m\&sig=96TE9FizbPJXuVZUxEcwCNT6wgo\&hl=en\&sa=X\&ei=3dbcVIXkHPbdsA Sn34KYBw\&ved=0CCAQ6AEwAQ\#v=onepage\&q=\%22Mr.\%20W.\%20R.\%20Grove\% 20on\%20a\%20new\%20Voltaic\%20Combination\%22\&f=false (accessed 11 November 2014).

Heldt, P.M. High Speed Combustion Engines: Design: Production: Tests. Philadelphia, PA: Chilton Company, 1956.

How Stuff Works. How Hydrogen Cars Work. http://auto.howstuffworks.com/fuelefficiency/hybrid-technology/hydrogen-cars2.htm (accessed 24 September 2014).

How Stuff Works. What's the energy efficiency ratio for hydrogen fuel cells?. http://auto.howstuffworks.com/fuel-efficiency/fuel-saving-devices/energy-efficiencyratio-hydrogen-fuel-cell1.htm (accessed 24 September 2014).

The Huffington Post. "Hydrogen Cars Showcased At Los Angeles Auto Show Could Be Future Of Transportation," 21 November 2013. http://www.huffingtonpost.com/2013/11/21/hydrogen-cars-la-autoshow_n_4317569.html.

Merriam-Webster. http://www.merriam-webster.com/dictionary/dependence, (accessed 26 September 2014).

Merriam-Webster. http://www.merriam-webster.com/dictionary/dependency (accessed 26 September 2014).

The New York Times. "EYES ON IRAQ; In Cheney's Words: The Administration Case for Removing Saddam Hussein,” 27 August 2002. http://www.nytimes.com/2002/08/27/world/eyes-iraq-cheney-s-words-administrationcase-for-removing-saddam-hussein.html.

The New Yorker. “The Rockefeller Brothers Fund Gives Up on Oil,” 23 September 2014. http://www.newyorker.com/business/currency/rockefellers-give-oil. 
Organization of the Petroleum Exporting Countries. Our Mission. http://www.opec.org/opec_web/en/about_us/23.htm (accessed 21 October 2014).

Rapier, Robert. “The Surprising Reason That Oil Subsidies Persist: Even Liberals Love Them.” Forbes, 25 April 2012. http://www.forbes.com/sites/energysource/2012/04/25/thesurprising-reason-that-oil-subsidies-persist-even-liberals-love-them/.

Smithsonian Institute. Fuel Cell History. http://americanhistory.si.edu/fuelcells/pem/pem2.htm (accessed 11 November 2014).

Stefanova, Katina. "Do Falling Oil Prices Foreshadow a Slump in the Stock Market in 2015?.” Forbes, 31 December 2014. http://www.forbes.com/sites/katinastefanova/2014/12/31/dofalling-oil-prices-foreshadow-a-slump-in-the-stock-market-in-2015/.

U.S. Department of Energy. Average Retail Price of Gasoline, 1929-2013. http://energy.gov/eere/vehicles/fact-835-august-25-average-annual-gasoline-pump-price1929-2013 (accessed 9 October 2014).

U.S. Department of Energy. Federal Tax Credits for Electric Vehicles Purchased in or after 2010. http://www.fueleconomy.gov/feg/taxevb.shtml (accessed 28 October 2014).

U.S. Department of Energy. Where the Energy Goes: Gasoline Vehicles. http://www.fueleconomy.gov/feg/atv.shtml (accessed 9 October 2014).

U.S. Energy Information Administration. “Annual Energy Outlook 2014.” http://www.eia.gov/forecasts/aeo/mt_liquidfuels.cfm (accessed 28 October 2014).

U.S. Energy Information Administration. “China.” http://www.eia.gov/countries/countrydata.cfm?fips $=$ ch (accessed 9 October 2014).

U.S. Energy Information Administration. "How much oil is consumed in the United States?.” http://www.eia.gov/tools/faqs/faq.cfm?id=33\&t=6 (accessed 21 October 2014).

U.S. Energy Information Administration. “OPEC Revenues Fact Sheet.” http://www.eia.gov/countries/regions-topics.cfm?fips=OPEC (accessed 21 October 2014).

U.S. Energy Information Administration. s.v. "biofuel." http://www.eia.gov/tools/glossary/index.cfm?id=B (accessed 29 October 2014).

US Department of Defense. "Quadrennial Defense Review 2014." Washington DC.

United States Census Bureau. Table P-1. CPS Population and Per Capita Money Income, All Races: 1967 to 2013. https://www.census.gov/hhes/www/income/data/historical/people/2013p01AR.xls (accessed 9 October 2014). 
United States Department of Transportation. Bureau of Transportation Statistics. http://www.rita.dot.gov/bts/sites/rita.dot.gov.bts/files/publications/national_transportation _statistics/html/table_01_11.html (accessed 6 November 2014).

United States Environmental Protection Agency. National Ambient Air Quality Standards (NAAQS), Carbon Monoxide (CO) Standards.

http://www.epa.gov/ttn/naaqs/standards/co/s_co_index.html (accessed 4 February 2015).

United States Patent and Trademark Office. U.S. Patent Activity Calendar Years 1790 to the Present. http://www.uspto.gov/web/offices/ac/ido/oeip/taf/h_counts.htm (accessed 6 November 2014)

The White House. “National Security Strategy,” February 2015.

The White House. “National Security Strategy,” May 2010.

The White House. Public Papers of the Presidents of the United States: Barack Obama, 2009, Book 1. U.S. Government Publishing Office, 2009. http://www.gpo.gov/fdsys/pkg/PPP2009-book1/pdf/PPP-2009-book1.pdf. 